\title{
Ausgabe 4 \\ Medizin mit Durchblick
}

Zum 4. Mal gibt die Deutsche Röntgengesellschaft das Patientenmagazin „Medizin mit Durchblick“ heraus: Am 15. Dezember erscheint die neue Ausgabe! In diesem Heft geht es vor allem um die Themen Schädel-Hirn-Trauma, Myome, um die virtuelle Autopsie und nicht zuletzt die Person Wilhelm Conrad Röntgen selbst. Wir sprechen über seine Erfolge, und wir lüften einige private Geheimnisse um den berühmten Erfinder der X-Strahlen.

„Medizin mit Durchblick“ ist eine Zeitschrift, die die DRG für Ihre Klinik oder Praxis publiziert: Es bringt Patienten die Welt der Radiologie nahe und verkürzt die Zeit im Wartezimmer. Bestellen Sie bequem online unter www.drg.de.

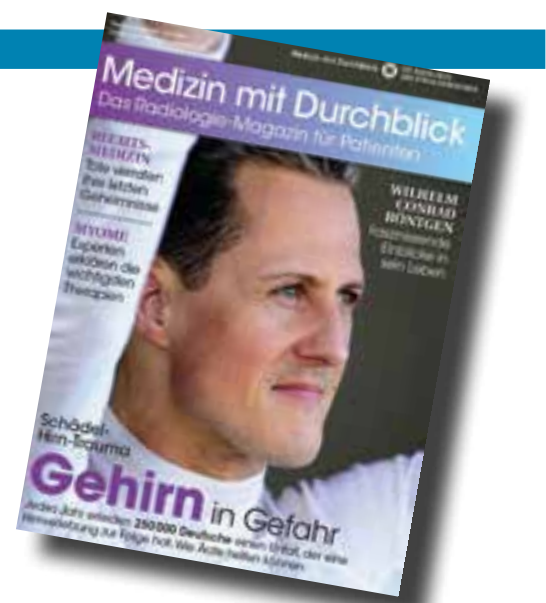

